\title{
Cocoa Pod Husk Biochar Reduce Watering Frequency and Increase Cocoa Seedlings Growth
}

\author{
Andi Bahrun*, Muhammad Yunus Fahimuddin, Tresjia Corina Rakian, La \\ Ode Safuan and La Ode Muhammad Harjoni Kilowasid
}

\author{
${ }^{1}$ Agrotechnology Department, Agricultural Faculty, Halu Oleo University, Jl. HEA. Mokodompit Kampus Hijau Bumi \\ Tridharma Anduonuhu, Kendari, Sulawesi Tenggara 93232, Indonesia \\ Email $^{1 *}$ :andibahrun@yahoo.co.id
}

\begin{abstract}
Biochar amount applied in the growing soil medium may decrease water use of cocoa seedling during dry season and hence may increase water use efficiency, thus a polybag experiment was carried out in the Glasshouse Agricultural Faculty, Halu Oleo University, Kendari, Southeast Sulawesi Indonesia in 2016to evaluate the effect of cocoa pod husk (CPH) biochar and watering frequencies on growth of cocoa seedlings.The experiment was arranged in a randomized block design with seven cacao pod husk (CPH) biocharlevels (without $\mathrm{CPH}$ biochar, $3 \mathrm{~g} \mathrm{CPH}$ biochar $\mathrm{kg}^{-1}$ soil, $6 \mathrm{~g} \mathrm{CPH}$ biochar $\mathrm{kg}^{-1}$ soil, $9 \mathrm{~g} \mathrm{CPH}$ biochar $\mathrm{kg}^{-1}$ soil, $12 \mathrm{~g} \mathrm{CPH}$ biochar $\mathrm{kg}^{-1}$ soil, $15 \mathrm{~g}$ CPH biochar $\mathrm{kg}^{-1}$ soil dan $18 \mathrm{~g}$ $\mathrm{CPH}$ biochar $\mathrm{kg}^{-1}$ soil) and three watering frequencies ( every two days, every four days and every six days) in three replications. Results showed that CPH biochar and watering frequency significantly influenced soil moisture. The rate of $\mathrm{CPH}$ biochar amendment determined watering frequency and cocoa seedling growth rate. $\mathrm{CPH}$ biochar improved cocoa seedling growth and reduced watering frequency. Cocoa seedlings treated with $9 \mathrm{~g}$ $\mathrm{CPH}$ biochar $\mathrm{kg}^{-1}$ soil and $60 \mathrm{~g} \mathrm{CPH}$ biochar $\mathrm{kg}^{-1}$ soil with every six days of WF increased WUE by $208.8 \%$ and $262.22 \%$, respectively, compared to no biochar application.
\end{abstract}

Keywords-biochar, cacao, growth, rate, soil, water.

\section{INTRODUCTION}

Increasing cocoa production and improving quality of cocoa seedling is a major target to meet the domestic and export demand since Southeast Sulawesi as a national area center of cocoa development in Indonesia. Cocoa (Theobroma cacao L) seedlings require a significant amount of nutrient and water for their proper growth and development. It has been reported that water being essential in growth and development of plants, a specific amount of water is needed for optimum growth and very large amount of water required to sustain seedlings growth is obtained primarily from the soil. [1] regular watering for tree nurseries is necessary to produce good quality seedlings at economic rate.

The amount of water in the soil varies widely over time and almost never is ideal for maximum absorption by roots. Usually there is too much or too little water in the soil, and mostly the latter. The major sources of water for seedlings in the nursery phase are irrigation water. However, a portion of this water is lost by surface run off and some evaporates before it can percolate into the soil. The amount that is lost by evaporation varies with atmospheric conditions and with soil texture, color, and porosity [2]. The big challenges for obtaining high quality of seedling in the nursery growing period during dry season with the current trend of changed weather are limited water resources, therefore, seedling frequently exposed to drought conditions.

Drought is one of the main limiting factors affecting seedling growth in Indonesia. Drought decreases soil moisture content by evaporation and limits water availability to seedling root systems [3]. Seedlings close their stomata during drought and photosynthesis is stopped, resulting in seedling mortality due to"carbon starvation" [4]. This conditions has in a long way discouraged the farmer leading to fall in the level of production of high quality of seedling to be transplated in the field. The possible approach to addressing those constraints to obtain the high quality of seedlings is the application of biochar and regulating water applied. Biochar amendment may be a viable means of mitigating current water shortages on drought-prone soils and future water shortages accompanying climate change [5].

Biochar has been proposed as a beneficial amendment concerning various agricultural and environmental aspects such as increasing soil fertility, retaining water in the soil and enhancing plant growth [6]. Most biochars 
made from plant materials have a high porosity and surface area [7] and thus a large capacity to hold water at field capacity [8]. Biochar application improves nutrient availability and water holding capacity for supporting plant growth [9,10]. Biochar from cocoa pod husk influenced soil temperature, soil moisture and seedling growth [11]. Research reports have been shown that biochar addition significantly increased the available water contents of the soils by both increasing the amount of water held at field capacity, allowing plants to draw the soil to a lower water content before wilting and increase produktivity in drought-prone regions or reduce the frequency of irrigation [5]. This indicates that biochar applied into the growing soil medium may decrease water irrigation for cocoa seedlings during dry season and may, therefore, increase water use efficiency. Thus, CPH biochar has the potential to be used as a material for improving growth and water use efficiency of cocoa seedlings. It would therefore be important to also study growth of cocoa seedling under different rate of biochar and watering frequencies. The aim of the current study was to investigate the effects of $\mathrm{CPH}$ biochar and watering frequencies on growth and water use efficiency of cocoa seedlings.

\section{MATERIAL AND METHODS}

A polybag experiment was conducted in the Glasshouse of Agricultural Faculty, Halu Oleo University, Kendari, Southeast Sulawesi Indonesia, 2016. The experiment was arranged in a randomized block design with seven levels of cacao pod husk (CPH) biochar (i.e. without $\mathrm{CPH}$ biochar, $3 \mathrm{~g}$ CPH biochar $\mathrm{kg}^{-1}$ soil, $6 \mathrm{~g} \mathrm{CPH}$ biochar $\mathrm{kg}^{-1}$ soil, 9 g CPH biochar $\mathrm{kg}^{-1}$ soil, $12 \mathrm{~g} \mathrm{CPH}$ biochar kg-1 soil, $15 \mathrm{~g} \mathrm{CPH}$ biochar $\mathrm{kg}^{-1}$ soil dan $18 \mathrm{~g} \mathrm{CPH}$ biochar kg${ }^{1}$ soil) and three levels of watering frequencies (i.e. every two days (V0), every four days (V1) and every six days (V2)) in three replications. The mean daily temperatures in the glasshouse varied from $22^{\circ} \mathrm{C}$ to $30^{\circ} \mathrm{C}$, and the relative humidity ranged from $68 \%$ to $88 \%$.

Biochar was produced from cocoa pod husk (CPH) by using a drum kiln, in which carbonization was done within 4-6 $\mathrm{h}$ [12]. The hot biochar produced after pyrolysis was quenched with distilled water, collected, air-dried, crushed and sieved through a $2 \mathrm{~mm}$ sieve before being used. The soil for trial was collected from the sandy loam (76\% sand, $21 \%$ silt and $11 \%$ clay) of the experimental farm of Agricultural Faculty, Halu Oleo University.

Cacao seedlings were raised on germination media for 14 days and each seedling was then transplanted into a polybag $(25 \mathrm{~cm}$ X $30 \mathrm{~cm}$ size $)$ seedling madia which have been filled with $5 \mathrm{~kg}$ dry soilmixed witha treatmentbased rate of biochar from cacao podhusks $(0.5 \mathrm{~mm}$ particle size) at a planting space $20 \mathrm{cmx} 20 \mathrm{~cm}$ [11). The amount of water applied was $200 \mathrm{ml}$ per plant for the three months under glasshouse conditions with a frequency depending on the given treatment. Seedling growth and soil moisture were monitored for three consecutive months. The data collected include: seedling height, number of leaves, leaf area, root dry weight,shoot dry weight and water use efficiency. The soil moisture was monitored with asoil moisture meter (model: PMS714), while soil temperature with soil thermometer at the depth of $12 \mathrm{~cm}$ below the surface every two days at 17.00 pm (before being irrigated). Seedling height, number of leaves and leaf area were measured 90 days after planting. Thereafter, seedlings were removed from the nursery and sent to the laboratory, in order to obtain their dry weight of root and shoot. Dry weight was obtained after drying the material at $85{ }^{\circ} \mathrm{C}$ for 48 hours. The WUEwas determined by using the formula: WUE= shoot dry weight (g)/total water use (L) [13]. Data were analyzed by using anova followed by Duncan's multiple test at an error rate of $5 \%(\mathrm{P}<0.05)$.

\section{RESULTS AND DISCUSSIONS}

As shown in Figure 1, biochar from cocoa pod husk $(\mathrm{CPH})$ and watering frequencies (WF) significantly influenced soil moisture. Soil moisture increased with an increase in $\mathrm{CPH}$ biochar rate at different WF. The rate of $\mathrm{CPH}$ biochar application determined soil moisture at all WF treatments. Our results showed that $\mathrm{CPH}$ biochar maintained soil moisture even at every six days of WF. This indicates that $\mathrm{CPH}$ biochar could retain moisture and minimize WF, therefore, less water was required for cacao seedling growth. The application of biochar improves soil structure [8] and improves the soil's ability to retain moisture [14,15]. Further, $\mathrm{CPH}$ biochar increases pore aeration and water availability [10]. The significant increase in soil moisture under treatment of $\mathrm{CPH}$ biochar was in conformity with the findings that biochar amendment in soils increased the plant available water content $[16,17]$.

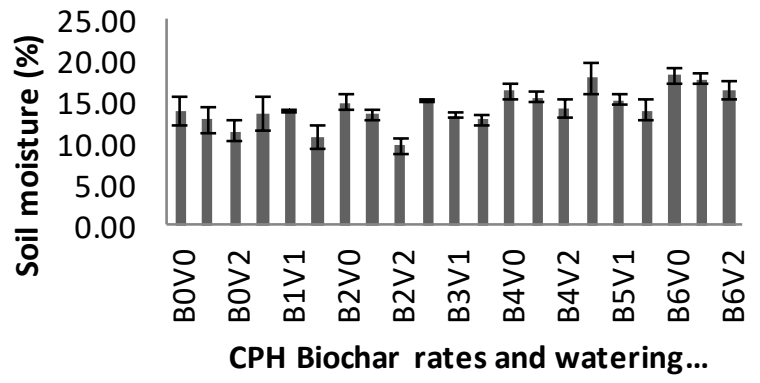

Fig.1: Effects of cocoa pod husk (CPH) biochar rates and watering frequencies on soil moisture. Error bars indicate standard deviations. 
Cocoa seedlings grown on soils treated with $6 \mathrm{~g} \mathrm{CPH}$ biochar $\mathrm{kg}^{-1}$ soil with every four days of watering frequency were higher in dry root weight but insignificantly different from those treated with $3 \mathrm{~g} \mathrm{CPH}$ biochar $\mathrm{kg}^{-1}$ soil with every four and six days of WF and other rates of $\mathrm{CPH}$ biochar at different WF (Figure 3a). This indicates that small amount of $\mathrm{CPH}$ biochar improved root growth due to the capacity of $\mathrm{CPH}$ biochar in increasing water holding capacity. Dose of $\mathrm{CPH}$ biochar exceeding $6 \mathrm{~g}$ CPH biochar $\mathrm{kg}^{-1}$ soil significantly decreased root dry weight due to high soil moisture (Figure 1). This means that $\mathrm{CPH}$ biochar greatly influences root growth and root growth may be determined by soil water conditions. Root development is largely influenced by the soil moisture. This strengthens the previous findings that soil water content was a crucial component that influenced root growth [18], with possible affects on leaf growth and cocoa seedling growth as a whole. A positive influence on plant growth and development due to the plant available water content is increased [19].

As shown in Figure 2 and 3, CPH biochar and WF significantly affected seedling height, number of leaves, leaf area, root dry weight and shoot dry weight of cocoa seedling. Cocoa seedlings grown on soils treated with $9 \mathrm{~g}$ $\mathrm{CPH}$ biochar $\mathrm{kg}^{-1}$ soil with every four days of WF were higher in plant height, number of leaves, leaf area and dry shoot weight of cocoa seedling, but insignificantly different from cocoa seedlings grown on soils without $\mathrm{CPH}$ biochar with every two days of $\mathrm{WF}$ and $9 \mathrm{~g} \mathrm{CPH}$ biochar $\mathrm{kg}^{-1}$ soil with every six days of WF. This clearly indicates that adding $\mathrm{CPH}$ biochar can significantly affect cacao seedling growth and reduce WF. It means that $\mathrm{CPH}$ biochar increased both cocoa seedlings biomass and water use efficiency (Figure 3 and 4). The application of $9 \mathrm{~g}$ $\mathrm{CPH}$ biochar $\mathrm{kg}^{-1}$ soil increased seedling height, number of leaves, leaf area, and shoot dry weight of cocoa seedling. Similar results were reported by a number of researchers $[20,21,22,23]$ that biochar significantly increased plant growth and biomass. Our results also followed similar trends established in different studies involving application of biochar in increasing WUE. The greatest WUE (1.63 $\left.\mathrm{g} \mathrm{L}^{-1}\right)$ was found in the soils treated with $12 \mathrm{~g} \mathrm{CPH}$ biochar $\mathrm{kg}^{-1}$ soil with every six days of $\mathrm{WF}$ and the lowest was found in the soils without $\mathrm{CPH}$ biochar $\left(0.45 \mathrm{~L}^{-1}\right)$ application. Such a greatest WUE found in the former treatment was, however, not significantly different from cocoa seedlings treated with 9 g CPH biochar $\mathrm{kg}^{-1}$ soil with every six days of WF. Cocoa seedlings treated with $9 \mathrm{~g} \mathrm{CPH}$ biochar $\mathrm{kg}^{-1}$ soil and $12 \mathrm{~g}$ $\mathrm{CPH}$ biochar $\mathrm{kg}^{-1}$ soil with every six days of WF increased WUE by $208.8 \%$ and $262.22 \%$, respectively, compared to no biochar application. On the other hand, as $\mathrm{CPH}$ biochar rates exceeded $12 \mathrm{~g}$, the WUE tended to decrease at different WF. Our study showed that biochar was effective in increasing the WUE of cacao seedlings, however, the rates of biochar application should be considered.
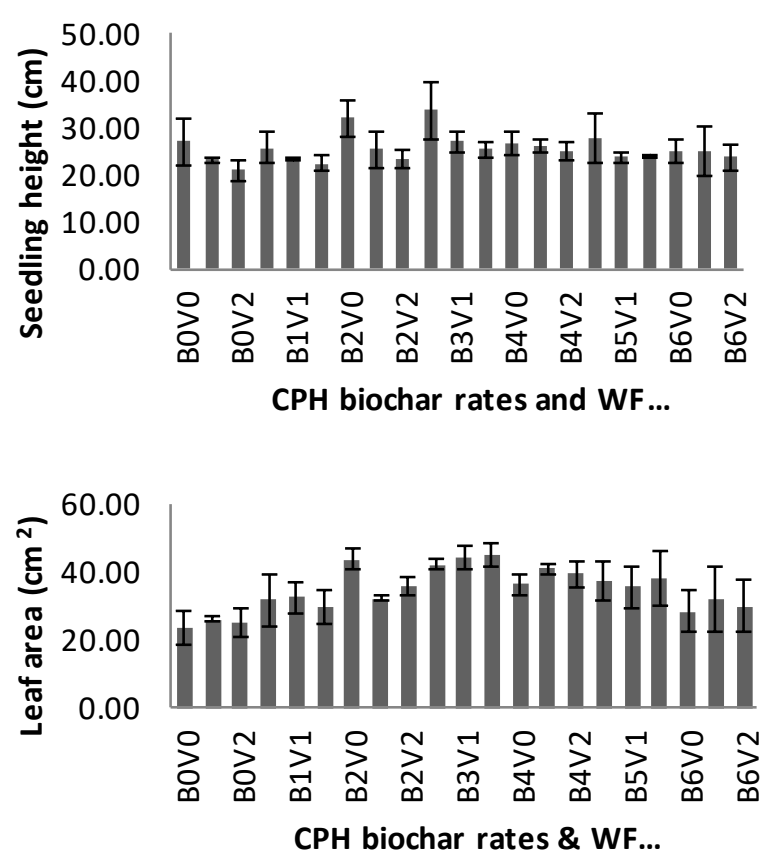

Fig.2: Effects of CPH biochar rates and watering frequencies on seedling height (a) and leafarea (b).

Error bars indicate standard deviations.

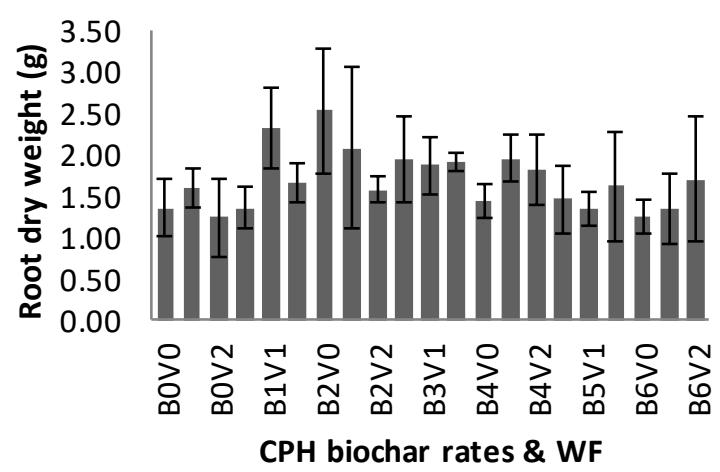

(a)

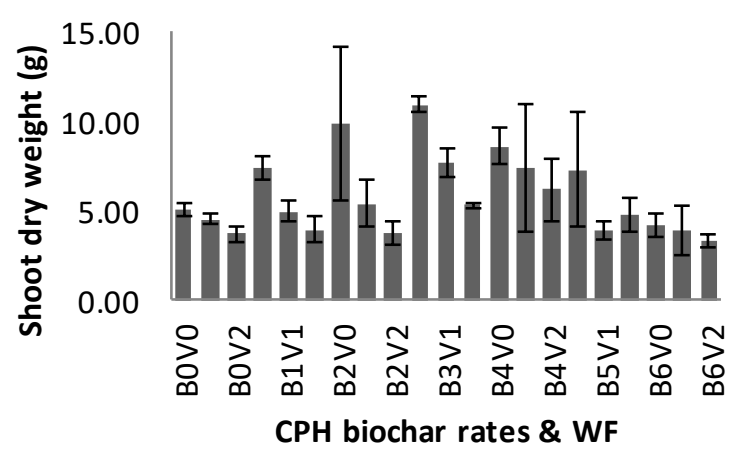

(b)

Fig.3: Effects of CPH biochar rates and watering frequencies on root dry weight (a) and shoot dry weight (b). Error bars indicate standard deviations. 


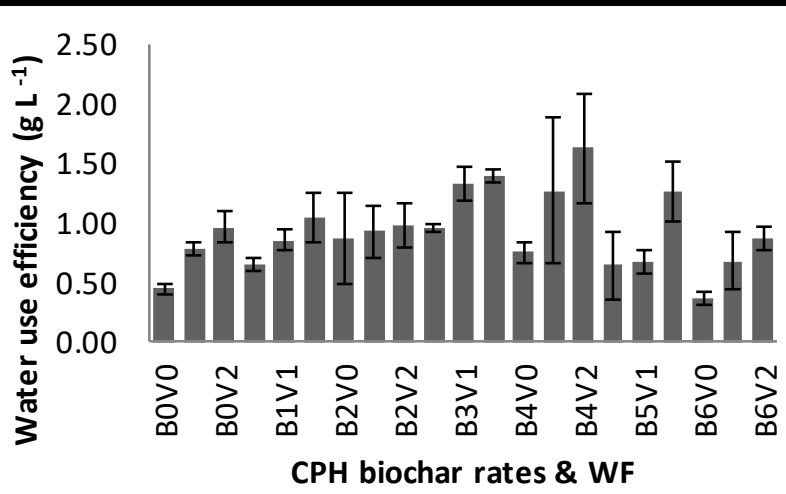

Fig.4: Effects of CPH biochar rates and watering frequencies on water use efficiency. Error bars indicate standard deviations.

In general, the results also showed that the biochar treatment exceeding $9 \mathrm{~g}$ CPH biochar $\mathrm{kg}^{-1}$ soil significantly decreased seedling growth. The above result has been reported by [11]. However, such a decrease in cocoa seedling growth rate also depended on WF. Interestingly, mean of cocoa seedling growth at a rate of $15 \mathrm{~g} \mathrm{CPH}$ biochar $\mathrm{kg}^{-1}$ soil and $18 \mathrm{~g} \mathrm{CPH}$ biochar $\mathrm{kg}^{-1}$ soil with every six days of WF was higher than those grown on soils treated with $\mathrm{CPH}$ biochar and every two days of WF. This is presumably a consequence of the big changes in soil moisture (Figure 1). The decrease in seedling growth may be due to great changes in soil bulk density, restricted aeration or higher soil moisture at a rate of $18 \mathrm{~g}$ $\mathrm{CPH}$ biochar $\mathrm{kg}^{-1}$ soil compared to without biochar and the other treatments (Figure 1). This indicates that roots were exposed to limited oxygen and high water content conditions [11]. Lack of oxygen content in the soils may be damaged of root development[24]. This is similar to findings by [25] who found reduced permeability to water due to poor aeration may cause decreased tree growth.

\section{CONCLUSION}

Results showed that $\mathrm{CPH}$ biochar and watering frequency significantly influenced soil moisture. The rate of $\mathrm{CPH}$ biochar amendment determined watering frequency and cacao seedling growth rate. CPH biochar improved cacao seedling growth and reduced watering frequency. Cacao seedlings treated with $9 \mathrm{~g} \mathrm{CPH}$ biochar $\mathrm{kg}^{-1}$ soil and $12 \mathrm{~g}$ $\mathrm{CPH}$ biochar $\mathrm{kg}^{-1}$ soil with every six days of WF increased WUE by $208.8 \%$ and $262.22 \%$, respectively, compared to no biochar application. Application of $9 \mathrm{~g}$ $\mathrm{CPH}$ biochar $\mathrm{kg}^{-1}$ soil and $12 \mathrm{~g} \mathrm{CPH}$ biochar $\mathrm{kg}^{-1}$ soil are recommended for increasing growth and water use efficiency of cocoa seedling.

\section{ACKNOWLEDGEMENTS}

This paper is a part of the data research funded by the Ministry of Research, Technology and Higher Education of Republic Indonesia in 2016. We would like to send our gratitude and appreciation to the Ministry for providing the grant for this work. Part of this manuscript has been presented by the first author in the "International Conference on Sustainable Soil Management " 4 to 7,April, 2017 Sarawak Malaysia.

\section{REFERENCES}

[1] Simon A. Mng'omba, Festus, K., Akinnifesi, Gudeta, S., Oluyede C., Ajayi., Betserai., Nyoka and Ramni J. 2011. Water application rate and frequency affect seedling survival and growth of Vangueria infausta and Persea Americana. African Journal of Biotechnology Vol. 10(9), pp. 1593-1599, 28.

[2] Kozlowski, T.T. 1987. Soil mositure and absorption of water by tree roots.Journal of Arboriculture 13 (2): $39-46$

[3] Grossnickle, S. C. 2005. Importance of root growth in overcoming planting stress. New Forests, 30(2-3), 273-294

[4] McDowell, N., W.T. Pockman., C.D. Allen., D.D. Breshears., N. Cobb., T. Kolb., J. Plaut., J. Sperry., A. West., D.G. Williams., and Yepez, E.A. 2008. Mechanisms of plant survival and mortality during drought: why do some plants survive while others succumb to drought? New Phytol. 178:719-739.

[5] Koide, R.T, NGUYEN, B.T., Skinner, R.H., Dell, CJ.,, Peoples, M.S., Adler, P.R, \& Drohan, PJ.2015. Biochar amendment of soil improves resilience to climate change.GCB Bioenergy, 7, 1084-1091.doi: 10.1111/gcbb.12191.

[6] Zimmerman, A.R. 2010. Abiotic and microbial oxidation of laboratoryproduced black carbon (biochar). Environ. Sci. Technol. 44:1295-1301. doi:10.1021/es903140c

[7] Downie D, Crosky A, and Munroe P. 2009. Physical properties of biochar. In: Biochar for Environmental Management: Science and Technology (eds Lehmann J, Joseph S), pp. 13-31. Earthscan, London.

[8] Glaser, B., J. Lehmann, and W. Zech. 2002. Ameliorating physical and chemical properties of highly weathered soils in the tropics with charcoal: A review. Biol. Fertil. Soils 35:219-230.

[9] Kamara, A., Kamara,H.S., \& Kamara,M.S. 2015. Effect of rice straw biochar on soil quality and the early growth and biomass yield of two rice varieties. Agricultural 6: $\quad$ Science, http://dx.doi.org/10.4236/as.2015.68077.

[10] Sutono, S,. \& Nurida, N.L. 2012. The water holding capacity of biochar in sandy soil fraction. Jurnal Penelitian Ilmu-Ilmu Kealaman: Buana Sains. Tribhuana Press.Vol 12 (1): 45-52.

[11] Bahrun, A., Fahimuddin. M.Y., Safuan, L., Kilowasid.L.M.H., and Singh,R. 2018. Effects of 
cocoa pod huskbiochar on growth of cocoa seedlings in Southeast Sulawesi-Indonesia. Asian J. Crop Sci., 10: 22-30.

[12] Pari, G., H. Raliadi and S. Komarayati, 2013. Biochar for forestry and agricultural production. Proceeding of the National Workshop on Biochar for Food Security: Learning from Experiences and Identifying Research Priorities, February 4-5, 2013, Bogor, West Java, Indonesia, pp: 5-10.

[13] Bahrun ,A., Hasid, R., Muhidin., and Erawan, D. 2012. The effect of partial root zone irrigation on water efficiency and yield of soybean (Glycine max L.) during dry season. J. Agron. Indonesia 40(1):3641.

[14] Karhu K., Mattila T., Bergstrom \& Regina K. 2011. Biochar addition to agricultural soil increased $\mathrm{CH} 4$ uptake and water holding capacity - Results from a short-term pilot field study. Agriculture, Ecosystems \& Environment, 140:309-313.

[15] Laird D.A., Fleming P., Davis D.D., Horton R., Wang B., and Karlen D.L. 2010. Impact of biochar amendments on the quality of a typical Midwestern agricultural soil. Geoderma, 158:443-449

[16] Atkinson, C.J., Fitzgerald, J.D., and Hipps, N. 2010. Potential mechanisms for achieving agricultural benefits from biochar application to temperate soils: a review. Plant Soil 337:1-18

[17] Castellini, M., Giglio,L., Niedda, M., Palumbo, A.D., and Ventrella, D. 2015. Impact of biochar addition on the physical and hydraulic properties of a clay soil. Soil Tillage $\quad$ Res. 154: 1-13. Doi:http//dx.doi.org/10.1016/j-still.2015.06.016.

[18] Gaochao Cail, Jan Vanderborght, Matthias Langensiepen, Andrea Schnepf, Hubert Hüging ,and Harry Vereecken. 2018. Root growth,water uptake,and sap flow of winter wheat in response to different soil water conditions. Hydrol. Earth Syst. Sci., 22, 2449-2470, 2018 https ://doi.org/10.5194/hess -22-2449-2018

[19] Haider, G., Koyro, H.W., Azam,F., Steffens, D., Muller,C., and Kammann, C. 2015. Biochar but not humic acid product amendment affected maize yields via improving plant-soil moisture relations. Plant Soil, 395:141-157.

doi :http://dx.doi.org/10.1007/211104-014-2294-3.

[20] Deal, C., Brewer, C.E., Brown, R.C., , Okure, M.A. E., and Amoding, A. 2012. Comparison of kilnderived and gasifier-derived biochars as soil amendments in the humid tropics. Biomass and Bioenergy, 37, 161-168.

[21] Uzoma, K.C., M. Inoue, H. Andry, H. Fujimaki, Z. Zahoor, and E. Nishihara.2011. Effect of cow manure biochar on maize productivity under sandy soil condition. Soil Use Manage. 27:205-212.
[22] Major, J., Rondon, M., Molina, D., Riha, S.J. and Lehmann, J. 2010. Maize yield and nutrition after 4 years of doing biochar application to a Colombian savanna Oxisol.Plant and Soil 333:117-128.

[23] Kimetu, J.M., J. Lehmann, S.O. Ngoze, D.N. Mugendi, J.M. Kinyangi, S. Riha, L.Verchot, J.W. Recha, and A.N. Pell. 2008. Reversibility of soil productivity decline with organic matter of differing quality along a degradationgradient. Ecosystems 11:726-739. doi:10.1007/s 10021-008-9154-z

[24] Schumacher, T. E. \& Smucker, A. J. M. 1984. Effect of soil compaction on root growth and uptake of phosphorus. Plant and Soil, 77: 15-28.

[25] Grigal, D.F., 2000. Effects of extensive forest management on soil productivity.For. Ecol. Manage. 138, 167-185. 